\title{
The application of endoscopic surgery in orbital sinusogenous complications in ENT Clinic CM U] Krakow in 2004-2016
}

\section{Zastosowanie wewnątrznosowej chirurgii endoskopowej u chorych leczonych w Klinice Otolaryngologii SU w Krakowie w latach 2004-2016 z powodu powikłań oczodołowych zapalenia zatok przynosowych}

\author{
Agata Augustyniak, Paweł Stręk \\ Szpital Uniwersytecki w Krakowie, Oddział Kliniczny Otolaryngologii; Kierownik Oddziału Klinicznego Prof. dr hab. med. Jacek Składzień
}

Article history: Received: 09.06.2017 Accepted: 15.02.2018 Published: 30.03.2018

ABSTRACT:

Introduction: Endoscopic surgery of the paranasal sinuses is a surgical technique that has revolutionized the surgical treatment of patients with chronic sinusitis. Application of this method now goes far beyond the conditions of the nasal cavity.

Aim: It allows among other operations within the eye socket, acting alternative technique for the operation of the external appproauch.

Material and Methods: This work is devoted to the analysis of the effectiveness of endoscopic surgery in the treatment of patients with orbital complications in the course of sinusitis in the Department of Otolaryngology SU in Cracow in the years 2004--2016, aim of this study is to search for optimal treatment of patients with the above disorders.

Results: In the group of patients operated on because of orbital abscess from reaching the outside in all patients had symptoms of revocation on the part of the orbit and ocular, and postoperative complications were not observed. Among patients undergoing endoscopic trocar in one patient there was no improvement in the function of the eye. It could lead to a too long period of time from the first appearance of symptoms (over 48 hours), and sometimes surgical intervention, as well as the occurrence of orbital hematoma in the second postoperative day and the necessity of re-operation of the external handle.

KEYWORDS: $\quad$ orbital abscess, orbital phlegmon, intraorbital complications, sinusitis

STRESZCZENIE: Wprowadzenie: Endoskopowa chirurgia zatok przynosowych jest techniką operacyjną, która zrewolucjonizowała chirurgiczne leczenie chorych z przewlekłym zapaleniem zatok przynosowych. Zastosowanie tej metody obecnie znacznie wykracza poza obręb schorzeń jamy nosowej. Technika ta umożliwia między innymi wykonywanie operacji w obrębie oczodołu, stanowiąc alternatywę dla operacji z dojścia zewnętrznego.

Cel pracy: Celem pracy jest poszukiwanie optymalnego sposobu leczenia pacjentów z powikłaniami oczodołowymi w przebiegu zapalenia zatok przynosowych.

Materiał i metody: Niniejsza praca poświęcona jest analizie skuteczności chirurgii endoskopowej u chorych z powikłaniami oczodołowymi w przebiegu zapaleń zatok przynosowych leczonych w Klinice Otolaryngologii SU w Krakowie w latach 2004-2016.

Wyniki: W grupie pacjentów operowanych z powodu ropnia oczodołu z dojścia zewnętrznego u wszystkich nastąpiło cofnięcie objawów ze strony oczodołu i narządu wzroku, a w okresie pooperacyjnym nie zaobserwowano powikłań. Wśród 
pacjentów operowanych z dojścia endoskopowego u jednego chorego nie wystąpiła poprawa funkcji narządu wzroku. Mogło się to wiązać ze zbyt długim czasem, jaki upłynął od pojawienia się pierwszych objawów do przeprowadzenia interwencji chirurgicznej (powyżej 48 godzin), a także z wystąpieniem krwiaka oczodołu w 2. dobie pooperacyjnej i-wobec powyższego - koniecznością wykonania reoperacji z dojścia zewnętrznego.

Wnioski: Z naszych doświadczeń wynika, że endoskopowe operacje drenażu ropnia oczodołu są skuteczne, a ich wyniki porównywalne do operacji przeprowadzanych z dojścia zewnętrznego.

SŁOWA KLUCZOWE: ropień oczodołu, ropowica oczodołu, powikłania wewnątrzoczodołowe, zapalenie zatok przynosowyc

\section{INTRODUCTION}

Bacterial infection of the orbit is usually caused by spreading of the infection from paranasal sinuses. It is most commonly caused by ethmoid sinusitis, however, all paranasal sinuses can be affected. It results from anatomical proximity of the orbit to paranasal sinuses [1]. Children are most commonly affected, however, all age groups are at risk [2].

Spreading to the orbit is associated with the risk of permanent damage of vision (limited eye mobility, impaired acuity of vision, even blindness), permanent neurological deficits, or can be even life-threatening. Due to the dramatic course of orbital complications of sinusitis, they are classified as emergencies with possible loss of vision $[3,4,5,6]$.

In diagnostics, computed tomography is used, which is an optimal tool to assess development and severity of complications. Magnetic resonance is not as useful in evaluating orbital complications as it is in the case of intracranial complications $[6,7,8]$. Intraoperative ultrasound is gaining popularity in evaluating the effectiveness orbital abscess drainage [9]. Also, eye examination is necessary to assess vision.

The first classification of orbital complications was introduced in 1937 by Hubert et al., including five groups of complications. It reflected both the extension and localization of lesions [10]. The classification was updated in 1970 by Chandler, with respect to orbital septum [11]. The main point was to emphasize the significance of infection behind the septum, which may lead to loss of vision. Determining the precise infection site allows to choose appropriate treatment and make a decision about surgical intervention [12]. Chandler's classification of orbital complications of sinusitis includes cavernous sinus thrombosis, however, due to its location it is classified as an intracranial complication.

In the case of orbital periostitis, intravenous antibiotic therapy can often be sufficient. Inflammation of soft tissues does not require surgical intervention, however, surgical treatment of pus collection in the sinuses is necessary [2].
Surgical intervention is necessary in patients, in whom conservative treatment proved to be ineffective (increasing impairment of visual acuity or eye movement, no improvement in local condition after 48 hours of conservative treatment), as well as in patients with clinical signs and computed tomography imaging confirming orbital abscess [2,13]. Early diagnosis and appropriate treatment prevents loss of vision resulting from optic nerve compression or extraocular inflammation, or cavernous sinus thrombosis $[13,14]$.

Orbital abscess drainage is carried out simultaneously with sinus surgery in order to remove pus collections. Classic surgical technique of managing orbital complications includes abscess drainage by external incision in the medial corner as well as external opening of sinuses to remove purulent discharge [2].

Traditional intraorbital access can be divided into two main groups - the first group including access to the anterior half of the eyeball, the second group including access to the posterior half of the eyeball and apex of the orbit. Anterior orbital access (anterior half of the eyeball) usually does not involve removal of bone walls and is classically divided into four subgroups: medial, inferior, lateral and superior [15].

In contrast to anterior orbital surgery, where incisions bring wide access to surgical field, bone structures and the eyeball itself make surgery difficult when it is necessary to get access behind the equator of the eyeball. Such interventions may require removal of parts of bone walls for good control of the operative field. It is sometimes necessary to remove one or more walls to get access to the apex of the orbit. Lesions located in the medial retrobulbar part of the orbit may be excised preserving bone walls by applying transconjunctival medial orbitotomy. During this procedure, it is often necessary to transect the medial rectus muscle in order to create enough space to proceed with the operation [15].

Advances in endoscopic surgery make it possible to drain an orbital access and, at the same time, to perform sinus surgery from intranasal access [2]. The drainage route depends on the location of the abscess within the orbit. 
Tab. I. Chandler's classification of orbital sinusogenous complications.

\begin{tabular}{|c|c|c|}
\hline & TYPICAL SYMPTOMS & TREATMENT \\
\hline \multicolumn{3}{|l|}{ Preseptal inflammation } \\
\hline Periorbital cellulitis & $\begin{array}{l}\text { Inflammation of soft tissues of the orbit, no vision } \\
\text { impairment, no exophthalmos }\end{array}$ & Pharmacological, alternatively secondary abscess drainage \\
\hline \multicolumn{3}{|l|}{ Retroseptal inflammation } \\
\hline Orbital cellulitis & $\begin{array}{l}\text { Chemosis, exophthalmos, limited ocular motility, impaired } \\
\text { acuity of vision }\end{array}$ & Pharmacological, alternatively secondary abscess drainage \\
\hline $\begin{array}{l}\text { Orbital cellulitis with subperiosteal } \\
\text { abscess }\end{array}$ & $\begin{array}{l}\text { Asymmetrical exophthalmos, impaired ocular motility, } \\
\text { impaired acuity of vision }\end{array}$ & $\begin{array}{l}\text { Pharmacological, paranasal sinus surgery, subperiosteal } \\
\text { abscess drainage }\end{array}$ \\
\hline Orbital cellulitis with obrital abscess & $\begin{array}{l}\text { Exophthalmos, impaired ocular motility, impaired acuity of } \\
\text { vision }\end{array}$ & Pharmacological, orbital abscess drainage \\
\hline Cavernous sinus thrombophlebitis & $\begin{array}{l}\text { Chemosis, ophthalmoplegia, paralysis or paresis of cranial } \\
\text { nerves: III, IV, VI, V1, V2, bilateral exophthalmos, immobile } \\
\text { eyeballs }\end{array}$ & Pharmacological, paranasal sinus surgery, anticoagulation \\
\hline
\end{tabular}

An abscess of the medial part of the orbit can be drained by intranasal endoscopic ethmoidectomy preceded by total or partial resection of the middle nasal concha. During the procedure, the lamina papyracea is removed [16], an incision is made in the periostium, the orbital fat is displaced when needed and the inferior and medial rectus muscles are identified. It is helpful to get a wider view of the medial part of the orbit by using the anterior transseptal window, which also makes a perfect occasion to apply three- and four-handed surgical technique [15].

Orbital abscesses located superiorly or inferiorly are not as common as those located medially. They are much harder to drain from intranasal access and tend to relapse. Superior orbital abscesses can be evacuated between the anterior ethmoidal artery and natural opening of the frontal sinus with removal of the upper wall of the orbit. Inferior orbital abscesses can be drained through the maxillary sinus by removing inferomedial wall [17].

While drainage of medial orbital abscesses by intranasal endoscopic ethmoidectomy is widely accepted, superior and inferior orbital abscess drainage remains controversial and only external access techniques should be attempted [7].

Regardless of surgical access, intraorbital surgery requires great precision and focus in order to save anatomical structures involved in normal vision and to preserve good cosmetic effect. Decision on surgical access must be based on lesion location, its relations to anatomical structures of the orbit and suspicion on the underlying pathology. Each part of the orbit can be opened using various surgical methods (both external incision and endoscopy), however, visualization is different for each method [15].
Orbital surgery for complications of sinusitis is conducted intranasally, however, it has some limitations. Orientation during surgery can be limited due to inflammation of soft tissues, which can result in profuse bleeding $[2,6]$.

Complications of endoscopic surgery are not common. Impaired eye movement has been reported resulting in double vision. Visual acuity is highly dependent on preoperative condition $[18,19]$. Additionally, in the case of an incompletely drained abscess, pus may collect again postoperatively necessitating reoperation. Also, bleeding with formation of orbital hematoma can occur [9].

Use of intraoperative CT-guidance during classic nose and sinus endoscopy as well as orbital surgery brings numerous benefits. It helps monitor tool position in real time. It also helps decide on the extent of surgery and radicality of lesion excision. Thanks to that, the risk of complications due to an extensive access, tool manipulation and bleeding is lowered, and the time of surgery is shorter.

This article contains the efficacy analysis of endoscopic surgery in managing orbital complications of paranasal sinusitis in the Otolaryngology Department of the University Hospital in Cracow between the years 2004 and 2014. The aim is to seek optimal treatment of patients with above-mentioned pathologies.

\section{MATERIALS}

A retrospective analysis was conducted based on the medical records of 24 patients, including 8 females and 16 males treated in the Department of Otolaryngology of the University Hospi- 
Tab. II. List of studied cases.

\begin{tabular}{|c|c|c|c|c|c|c|c|}
\hline & $\begin{array}{l}\text { SEX } \\
\text { AGE }\end{array}$ & SYMPTOMS & PREVIOUS TREATMENT & $\begin{array}{l}\text { COMPLICATION } \\
\text { /CHANDLER'S } \\
\text { CLASSIFICATION }\end{array}$ & $\begin{array}{l}\text { AFFECTED } \\
\text { SIDE }\end{array}$ & TREATMENT & OUTCOME \\
\hline 1. & $\begin{array}{l}M \\
20\end{array}$ & $\begin{array}{l}\text { Since } 48 \text { hours: exophthalmos, } \\
\text { impaired acuity of vision and eye } \\
\text { motility, fever }\end{array}$ & None & $\begin{array}{l}\text { Subperiosteal } \\
\text { abscess in the } \\
\text { medial part of the } \\
\text { orbit / Stage III }\end{array}$ & Left & $\begin{array}{l}\text { Bilateral } \\
\text { frontosphenoethmoidectomy, } \\
\text { transnasal abscess drainage }\end{array}$ & $\begin{array}{l}\text { Resolution of } \\
\text { symptoms, normal } \\
\text { acuity of vision }\end{array}$ \\
\hline 2. & $\begin{array}{l}M \\
52\end{array}$ & $\begin{array}{l}\text { Progressing limitation of eye } \\
\text { movement for a few days, } \\
\text { chemosis, no acuity disturbances }\end{array}$ & IV antibiotics & $\begin{array}{l}\text { Orbital cellulitis / } \\
\text { Stage II }\end{array}$ & Right & $\begin{array}{l}\text { Bilateral } \\
\text { frontosphenoethmoidectomy } \\
\text { from nasal access }\end{array}$ & $\begin{array}{l}\text { Resolution of } \\
\text { symptoms, normal } \\
\text { acuity of vision }\end{array}$ \\
\hline 3. & $\begin{array}{l}M \\
30\end{array}$ & $\begin{array}{l}\text { Severe headaches for } 2 \text { weeks, } \\
\text { chemosis, no limitation of } \\
\text { ocularm otility, normal acuity of } \\
\text { vision }\end{array}$ & IV antibiotics & $\begin{array}{l}\text { Orbital cellulitis / } \\
\text { Stage II }\end{array}$ & Left & $\begin{array}{l}\text { Bilateral } \\
\text { frontosphenoethmoidectomy } \\
\text { from nasal access }\end{array}$ & $\begin{array}{l}\text { Resolution of } \\
\text { symptoms, normal } \\
\text { acuity of }\end{array}$ \\
\hline 4. & $\begin{array}{l}K \\
50\end{array}$ & $\begin{array}{l}\text { Normal acuity of vision, normal } \\
\text { ocular motility }\end{array}$ & IV antibiotics & $\begin{array}{l}\text { Subperiosteal } \\
\text { abscess in the } \\
\text { medial part of the } \\
\text { orbit / Stage III }\end{array}$ & Left & $\begin{array}{l}\text { Left-sided orbitotomy, left- } \\
\text { sided ethmoidectomy from } \\
\text { external access (medial part of } \\
\text { the orbit) }\end{array}$ & Normal vision \\
\hline 5. & $\begin{array}{l}M \\
24\end{array}$ & $\begin{array}{l}\text { Progressing palpebral edema and } \\
\text { chemosis for a few days, normal } \\
\text { acuity and motility }\end{array}$ & IV antibiotics & $\begin{array}{l}\text { Periorbital cellulitis } \\
\text { |Stage I }\end{array}$ & Right & $\begin{array}{l}\text { Bilateral } \\
\text { frontosphenoethmoidectomy } \\
\text { from nasal access }\end{array}$ & $\begin{array}{l}\text { Resolution of } \\
\text { symptoms, normal } \\
\text { acuity }\end{array}$ \\
\hline 6. & $\begin{array}{l}M \\
14\end{array}$ & $\begin{array}{l}\text { Palpebral edema for a few days, } \\
\text { normal motility and acuity }\end{array}$ & IV antibiotics & $\begin{array}{l}\text { Orbital cellulitis / } \\
\text { Stage II }\end{array}$ & Right & $\begin{array}{l}\text { Right-sided ethmoidectomy } \\
\text { from external access }\end{array}$ & $\begin{array}{l}\text { Resolution of } \\
\text { symptoms, normal } \\
\text { acuity }\end{array}$ \\
\hline 7. & $\begin{array}{l}M \\
57\end{array}$ & $\begin{array}{l}\text { Progressing impairment of } \\
\text { vision acuity for } 48 \text { hours with } \\
\text { exophthalmos, palpebral edema, } \\
\text { limited ocular motility }\end{array}$ & None & $\begin{array}{l}\text { Subperiosteal } \\
\text { abscess in the } \\
\text { medial part of the } \\
\text { orbit / Stage III }\end{array}$ & Left & $\begin{array}{l}\text { Bilateral } \\
\text { frontosphenoethmoidectomy. } \\
\text { Orbitotomy from nasal access. } \\
\text { On day two reoperated - } \\
\text { orbitotomy from external } \\
\text { access in the lateral part of } \\
\text { the orbit }\end{array}$ & $\begin{array}{l}\text { Blindness, normal } \\
\text { motility }\end{array}$ \\
\hline 8. & $\begin{array}{l}M \\
31\end{array}$ & $\begin{array}{l}\text { Palpebral edema for a few days, } \\
\text { normal vision, normal motility, no } \\
\text { signs of exophthalmos }\end{array}$ & IV antibiotics & $\begin{array}{l}\text { Orbital cellulitis / } \\
\text { Stage II }\end{array}$ & Left & $\begin{array}{l}\text { Left-sided } \\
\text { frontosphenoethmoidectomy } \\
\text { from nasal access }\end{array}$ & $\begin{array}{l}\text { Resolution of } \\
\text { symptoms, normal } \\
\text { acuity }\end{array}$ \\
\hline 9. & $\begin{array}{l}M \\
50\end{array}$ & $\begin{array}{l}\text { Progressing palpebral edema } \\
\text { for } 24 \text { hours, normal acuity and } \\
\text { motility }\end{array}$ & IV antibiotics & $\begin{array}{l}\text { Orbital cellulitis / } \\
\text { Stage II }\end{array}$ & Left & $\begin{array}{l}\text { Left-sided } \\
\text { frontosphenoethmoidectomy } \\
\text { from nasal access }\end{array}$ & $\begin{array}{l}\text { Resolution of } \\
\text { symptoms, normal } \\
\text { acuity }\end{array}$ \\
\hline 10. & $\begin{array}{l}\text { M } \\
49\end{array}$ & $\begin{array}{l}\text { Progressing palpebral edema for } \\
48 \text { hours with impaired acuity of } \\
\text { vision and ocular motility }\end{array}$ & None & $\begin{array}{l}\text { Subperiosteal } \\
\text { abscess in the } \\
\text { medial part of the } \\
\text { orbit / Stage III }\end{array}$ & Left & $\begin{array}{l}\text { Left-sided } \\
\text { frontosphenoethmoidectomy. } \\
\text { Abscess was evacuated from } \\
\text { nasal access }\end{array}$ & $\begin{array}{l}\text { Resolution of } \\
\text { symptoms, normal } \\
\text { acuity }\end{array}$ \\
\hline 11. & $\begin{array}{l}K \\
64\end{array}$ & $\begin{array}{l}\text { Exophthalmos for } 24 \text { hours with } \\
\text { impaired acuity of vision and } \\
\text { ocular motility }\end{array}$ & None & $\begin{array}{l}\text { Subperiosteal } \\
\text { abscess in the } \\
\text { medial part of the } \\
\text { orbit / Stage III }\end{array}$ & Left & $\begin{array}{l}\text { Uffenorde surgery on the left } \\
\text { side, abscess evacuation from } \\
\text { external access }\end{array}$ & $\begin{array}{l}\text { Resolution of } \\
\text { symptoms, normal } \\
\text { acuity }\end{array}$ \\
\hline 12. & $\begin{array}{l}K \\
63\end{array}$ & $\begin{array}{l}\text { Severe headaches for one week, } \\
\text { exophthalmos and limited ocular } \\
\text { motility for } 24 \text { hours }\end{array}$ & None & $\begin{array}{l}\text { Subperiosteal } \\
\text { abscess in the } \\
\text { medial part of the } \\
\text { orbit / Stage III }\end{array}$ & Left & $\begin{array}{l}\text { Left-sided } \\
\text { frontosphenoethmoidectomy. } \\
\text { Abscess was evacuated from } \\
\text { external access }\end{array}$ & $\begin{array}{l}\text { Resolution of } \\
\text { symptoms, normal } \\
\text { acuity }\end{array}$ \\
\hline 13. & $\begin{array}{l}M \\
42\end{array}$ & $\begin{array}{l}\text { Orbital pain, severe impairment } \\
\text { of visual acuity }\end{array}$ & IV antibiotics & $\begin{array}{l}\text { Orbital cellulitis / } \\
\text { Stage II }\end{array}$ & Left & $\begin{array}{l}\text { Left-sided endoscopic } \\
\text { frontosphenoethmoidectomy }\end{array}$ & $\begin{array}{l}\text { Resolution of } \\
\text { symptoms }\end{array}$ \\
\hline 14. & $\begin{array}{l}M \\
60\end{array}$ & $\begin{array}{l}\text { Exopthalmos, erythema and } \\
\text { edema of eyelids }\end{array}$ & $\begin{array}{l}\text { Oral antibiotics for } \\
\text { more than one day }\end{array}$ & $\begin{array}{l}\text { Orbital cellulitis / } \\
\text { Stage II }\end{array}$ & Left & IV antibiotics & $\begin{array}{l}\text { Resolution of } \\
\text { symptoms }\end{array}$ \\
\hline 15. & $\begin{array}{l}M \\
36\end{array}$ & $\begin{array}{l}\text { erythema and edema of eyelids } \\
\text { for } 24 \text { hours, normal motility and } \\
\text { acuity }\end{array}$ & None & $\begin{array}{l}\text { Periorbital cellulitis } \\
\text { /Stage I }\end{array}$ & Left & IV antibiotics & $\begin{array}{l}\text { Resolution of } \\
\text { symptoms }\end{array}$ \\
\hline 16. & $\begin{array}{l}K \\
58\end{array}$ & $\begin{array}{l}\text { Palpebral edema for } 48 \text { hours, } \\
49 \text {-year history of blindness }\end{array}$ & None & $\begin{array}{l}\text { Subperiosteal } \\
\text { abscess in the } \\
\text { medial part of the } \\
\text { orbit / Stage III }\end{array}$ & Right & $\begin{array}{l}\text { Uffenorde surgery on the right } \\
\text { side, abscess evacuation from } \\
\text { external access }\end{array}$ & $\begin{array}{l}\text { Resolution of } \\
\text { symptoms }\end{array}$ \\
\hline
\end{tabular}




\begin{tabular}{|c|c|c|c|c|c|c|c|}
\hline 17. & $\begin{array}{l}M \\
32\end{array}$ & $\begin{array}{l}\text { Palpebral edema, normal motility } \\
\text { and acuity }\end{array}$ & None & $\begin{array}{l}\text { Periorbital cellulitis } \\
\text { / Stage I }\end{array}$ & Right & $\begin{array}{l}\text { IV antibiotics Bilateral } \\
\text { frontoethmoidectomy from } \\
\text { nasal access }\end{array}$ & $\begin{array}{l}\text { Resolution of } \\
\text { symptoms }\end{array}$ \\
\hline 18. & $\begin{array}{l}K \\
65\end{array}$ & $\begin{array}{l}\text { Palpebral edema, impaired } \\
\text { upward movement, normal acuity }\end{array}$ & Oral antibiotics & $\begin{array}{l}\text { Orbital cellulitis / } \\
\text { Stage II }\end{array}$ & Right & $\begin{array}{l}\text { Right-sided } \\
\text { frontoethmoidectomy from } \\
\text { nasal access }\end{array}$ & $\begin{array}{l}\text { Resolution of } \\
\text { symptoms }\end{array}$ \\
\hline 19. & $\begin{array}{l}M \\
59\end{array}$ & $\begin{array}{l}\text { Palpebral edema, normal motility } \\
\text { and acuity }\end{array}$ & None & $\begin{array}{l}\text { Periorbital cellulitis } \\
\text { /Stage I }\end{array}$ & Left & $\begin{array}{l}\text { Left-sided frontoethmoidectomy } \\
\text { from nasal access }\end{array}$ & $\begin{array}{l}\text { Resolution of } \\
\text { symptoms }\end{array}$ \\
\hline 20. & $\begin{array}{l}M \\
42\end{array}$ & $\begin{array}{l}\text { Palpebral edema, impaired vision } \\
\text { acuity, normal motility }\end{array}$ & None & $\begin{array}{l}\text { Orbital cellulitis / } \\
\text { Stage II }\end{array}$ & Right & $\begin{array}{l}\text { Bilateral frontoethmoidectomy } \\
\text { from nasal access }\end{array}$ & $\begin{array}{l}\text { Resolution of } \\
\text { symptoms }\end{array}$ \\
\hline 21. & $\begin{array}{l}\mathrm{K} \\
8\end{array}$ & $\begin{array}{l}\text { Orbital pain, palpebral edema } \\
\text { of the right eye, elevated body } \\
\text { temperature }\end{array}$ & None & $\begin{array}{l}\text { Subperiosteal } \\
\text { abscess in the } \\
\text { medial part of the } \\
\text { orbit / Stage III }\end{array}$ & Right & $\begin{array}{l}\text { Right-sided } \\
\text { frontoethmoidectomy from } \\
\text { nasal access. Adenotomy }\end{array}$ & $\begin{array}{l}\text { Resolution of } \\
\text { symptoms }\end{array}$ \\
\hline 22. & $\begin{array}{l}M \\
34\end{array}$ & $\begin{array}{l}\text { Edema and erythema of frontal } \\
\text { region and orbital soft tissues, } \\
\text { normal acuity and motility }\end{array}$ & None & $\begin{array}{l}\text { Periorbital cellulitis } \\
\text { /Stage I }\end{array}$ & Right & IV antibiotics & $\begin{array}{l}\text { Resolution of } \\
\text { symptoms }\end{array}$ \\
\hline 23. & $\begin{array}{l}K \\
46\end{array}$ & $\begin{array}{l}\text { Palpebral edema, exophthalmos, } \\
\text { normal acuity }\end{array}$ & Oral antibiotics & $\begin{array}{l}\text { Orbital cellulitis / } \\
\text { Stage II }\end{array}$ & Right & $\begin{array}{l}\text { Bilateral frontoethmoidectomy } \\
\text { Pyocele drainage of the right } \\
\text { ethmoidal sinus from nasal } \\
\text { access }\end{array}$ & $\begin{array}{l}\text { Resolution of } \\
\text { symptoms }\end{array}$ \\
\hline 24. & $\begin{array}{l}K \\
43\end{array}$ & $\begin{array}{l}\text { Diplopia, limited ocular motility, } \\
\text { impaired vision acuity }\end{array}$ & None & $\begin{array}{l}\text { Orbital cellulitis / } \\
\text { Stage II }\end{array}$ & Right & $\begin{array}{l}\text { Right-sided } \\
\text { frontoethmoidectomy from } \\
\text { nasal access. Septoplasty }\end{array}$ & $\begin{array}{l}\text { Resolution of } \\
\text { symptoms }\end{array}$ \\
\hline
\end{tabular}

tal in Cracow between the years 2004 and 2016 due to orbital complications of chronic paranasal sinusitis. The youngest patient was 8 years old and the oldest was 65 . The mean age of patients was 43 . Five patients were admitted with inflammation chemosis, eleven patients with soft tissue infection of the orbit, and eight patients with subperiostial abscesses of the orbit.

\section{RESULTS AND DISCUSSION}

All patients received computed tomography scan of paranasal sinuses in order to determine the extent and type of underlying pathology. Our study was also the basis for determination of indications and the scope of surgical treatment. All patients were consulted by an ophthalmologist prior to surgery and 24-48 hours afterwards, as well as about one month after the procedure. Visual acuity, color distinction, fundus of the eye and ocular motility were examined, as well as the exophthalmos using Hertl exophthalmometer. Every patient, on the first day, received empiric intravenous broad-spectrum antibiotic therapy, which was later modified based on cultures. Regardless of surgical treatment, intravenous antibiotics were continued until resolution of inflammation. All patients discharged from hospital continued oral antibiotics until cessation of symptoms.

Eight patients were diagnosed with an orbital abscess. In six of them, progressive eye symptoms occurred: visual acuity impairment, limited ocular motility and exophthalmos. One patient complained on total loss of vision on the affected side, which, according to the patient's description, had been present for 49 years and was most likely the consequence of an orbital complication of sinusitis. The patients were qualified for surgical drainage of an abscess and resection of inflammatory lesions from paranasal sinuses. In four patients, purulent discharge was evacuated during endoscopy, while in four other an external access was applied. Those procedures were performed by different operators, and the type of surgical access was determined by preferences and experience of the surgeon.

On postoperative day two, one of the patients undergoing endoscopic abscess drainage presented with progressing exophthalmos. After a control sinus CT scan, the patient was reoperated and orbitotomy using an external access was performed, during which a hematoma in the cavity of an orbital subperiosteal abscess was evacuated. No improvement of vision was noted in that patient - ophthalmological examination six days after surgery showed "doubtful sensation of light". Progressing impairment of visual acuity was reported to have started earlier than 48 hours before hospitalization, and at the time of admission the patient reported total blindness of the eye. In the rest of the patients, follow-up showed total resolution of symptoms.

Out of eleven patients diagnosed with orbital inflammatory infiltration without abscess formation, ten patients were 
qualified for surgical treatment in order to remove infection site in paranasal sinuses - endoscopy was performed in nine of them, and an external access was utilized in one patient. The interventions were performed by different operators, and surgical access was determined by the experience of the surgeon. Conservative treatment was chosen in one patient with orbital inflammation due to satisfying effect of intravenous antibiotics, until complete resolution of symptoms. In all patients from this group, total resolution of orbital symptoms was observed.

Among patients with inflammatory infiltration of the eyelids, three patients underwent surgery for removal of infection sites located in paranasal sinuses - endoscopy was performed in each case. The rest of the patients were treated conservatively. Resolution of orbital symptoms was observed in all those patients.

\section{CONCLUSIONS}

The application of intranasal endoscopic surgery makes it possible to drain an orbital abscess and remove pus collections located within paranasal sinuses via nasal access. It allows for physiological drainage of paranasal sinuses and achieving perfect cosmetic outcome.

Intranasal endoscopic surgery results in lesser trauma to tissues of the orbit, smaller postoperative edema, and as a result shorter hospital stay [20].

Our experience indicates that endoscopic intranasal drainage of orbital abscesses is effective, and the results are similar to external access. The choice of surgical access should depend on the preference of surgical team performing the intervention.

\section{References}

1. Botting A.M., McIntosh D., Mahadevan M.: Paediatric pre- and post-septal peri-orbital infections are different diseases. A retrospective review of 262 cases. Int. J. Pediatr. Otorhinolaryngol.Mar 2008;72 (3): 377--383.

2. Pelton R.W., Smith M.E., Patel B.C. et al.: Cosmetic considerations in surgery for orbital subperiosteal abscess in children: experience with a combined transcaruncular and transnasal endoscopic approach. Arch. Otolaryngol. Head Neck Surg. 2003; 129: $652--655$.

3. Pereira K.D., Mitchell R.B., Younis R.T. et al.: Management of medial subperiosteal abscess of the orbit in children -- a 5 year experience. Int. J. Pediatr. Otorhinolaryngol. Jan. 1997; 38 (3): 247--254.

4. Ahmad R., Salman R., Islam S., Rehman A.: Cavernous Sinus Thrombosis As A Complication Of Sphenoid Sinusitis: A Case Report And Review Of Literature. Internet J. Otorhinolaryngol. 12 (1): Accessed June 26, 2014.

5. Deutsch E., Eilon A., Hevron I. et al.: Functional endoscopic sinus surgery of orbital subperiosteal abscess in children. Int. J. Pediatr. Otorhinolaryngol. 1996, $34(1-2), 181--190$.

6. Kastner J., Taudy M., Lisy J., Grabec P., Betka J.: Orbital and intracranial complications after acute rhinosinusitis. Rhinology., 2010 ; 48, 457--461.

7. Younis R.T., Anand V.K., Davidson B.: The role of computed tomography and magnetic resonance imaging in patients with sinusitis with complications. Laryngoscope. Feb. 2002; 112 (2): 224--229.

8. Noel L.P., Clarke W.N., MacDonald N.: (1990). “Clinical management of orbital cellulitis in children”. Canadian Journal of Ophthalmology. 1990; 25 (1): 11-16.

9. Lyson T., Sieskiewicz A., Rutkowski R., Kochanowicz J., Różozanska M., Rogowski M., Mariak Z.: Endoscopic drainage of orbital abscesses aided with intraoperative sonography. Neurol. Neurochir. Pol. 2014; 48 (5): 315--321.

10. Hubert L.: Orbital infections due to nasal sinusitis. NY State J. Med. 1937; 37: 1559., 1937

11. Chandler J.R., Langenbrunner D.J., Stevens E.R.: The pathogenesis of orbital complications in acute sinusitis. Laryngoscope. Sep. 1970; 80 (9): 1414--1428.

12. Mahalingam-Dhingra A., Lander L., Preciado D.A., Taylormoore J., Shah R.K.: Orbital and periorbital infections: a national perspective. Arch. Otolaryngol. Head Neck Surg.Aug 2011; 137 (8): 769--773.

13. Coenraad S., Buwalda J.:, Surgical Or or medical management of subperiosteal orbital abscess iln children: a critical of the literature. RhonologyRhinology., $2009 ; 47 ; 18--23$.

14. Jahnke K.: Rhinosurgery in diseases of the orbits. Fortschr. Kiefer Gesichtschir. 1996, 41: 44--49.

15. Dallan I., Castelnuovo P., Sellari-Franceschini S., Locatelli D.: Endoscopic orbital and transorbital approaches. 2016.

16. Gavriel H., Kessler A., Eviatar E.: Management implications of diagnosis orbital abcess as subperiosteal orbital abcess. Rhinology. 2010; 48, 90--94.

17. Rootman J., Steweart B., Goldberg R.A.: Orbital surgery - a. A conceptual approach. 2014.

18. Ikeda K., Oshima T., Suzuki H. et al.: Surgical treatment of subperiosteal abscess of the orbit: Sendai's ten-year experience. Auris Nasus Larynx. 2003, 30, 259--262.

19. Han J.K., Higgins T.S.: Management of orbital complications In endoscopic sinus surgery. Current Opinion In Otolaryngology \& Head and Neck Surgery. Feb 2010; 18 (1):, 32-36.

20. Noordzij J.P., Harrison S.C., Mason J.C., Hashisaki G.T., Reibel J.F., Gross Ch.W.:, Pitfalls iIn the eEndoscopic dDrainage of sSubperiosteal oOrbital aAbscesses aSecondary to sSinusitis. American Journal of Rhinology. March 2002; 16 (2): 97--101. 


\section{Word count: 2300 Tables: 2 Figures:- References: 20}

Access the article online: DOI: 10.5604/01.3001.0011.6793 Table of content: https://otorhinolaryngologypl.com/issue/10687

Corresponding author: Agata Augustyniak; Katedra i Klinika Otolaryngologii U] CM; ul. Śniadeckich 2, 31-531 Kraków, Polska; Tel.: +48 12 424 79 o0; e-mail: augustyniak_agata@poczta.fm

Copyright @ 2018 Polish Society of Otorhinolaryngologists Head and Neck Surgeons. Published by Index Copernicus Sp. z o.o. All rights reserved

Competing interests: The authors declare that they have no competing interests.

Cite this article as: Augustyniak A., Stręk P.: The application of endoscopic surgery in orbital sinusogenous complications in ENT Department, CM of JU in Krakow in 2004-2016; Pol Otorhino Rev 2018; 7(1): 24-30 